У, $\triangle \mathrm{K} 324: 316.334 .3$

ББК 66.3(0),131+66.3(0),4

DOI 10.22394/1682-2358-2017-3-140-146

A.O. Nesmashny, postgraduate student of the Political Sciences Department, Povolzhsky Institute of Manasement named after P.A. Stolypin, Branch of the Russian Presidential Academy of National Economy and Public Administration

\section{THE ROLE OF YOUTH IN THE ELECTION CAMPAIGN FOR THE RF STATE DUMA OF THE VII CONVOCATION}

A comparative analysis of activities of the parliamentary parties' youth departments in the RF State Duma election campaign in 2016 is drawn. The role and importance of youth departments in the election campaign is determined. The author identifies the specific aspects in the organization of relationships with youth departments and young people in each of the parliamentary parties.

Key words and word-combinations: political parties, State Duma of VII convocation, youth departments of Russian parliament parties, electoral campaign.
A.О. Несмашнъй, аспирант кафедрог политических наук Поволжского института упраљления имени П.А. Стольтина - филиала Российской академии народного хозяйства и государственной службь при Президенте РФ (етаil: nao@astpl.ru)

\section{РОАЬ МО ОАЕЖИ В ИЗБИРАТЕАЬНОЙ КАМПАНИИ В ГОСУААРСТВЕННУЮ АУМУ РФ VII СОЗЫВА}

Аннотацุия. Сравнивается деятельность молодежных отделений парламентских партий во время избирательной кампании 2016 г. в Государственную Думу РФ. Определяется роль и значение молодежных отделений в избирательной кампании. Выявляются особенности в организации взаимоотношений с молодежными отделениями и молодежью в каждой из парламентских партий.

Ключевые слова и словосочетания: политические партии, Государственная Дума VII созыва, молодежные отделения парламентских партий России, избирательная кампания.

M олодые мюди - особая категория граждан, вкцючая помитическую самореамизацию. История знает множество примеров, когда «молодежкный ресурс» играл решающую роль в значимых политических событиях страны [1].

Все партии в той или иной степени уАемяют внимание молодежной аудитории и возлагают на нее определенные надежды. Можно убедиться в этом, проанализировав 
программные документы парламентских партий РФ. Так, в Уставе партии «ЕАиная Россия» в разделе џелей и задач в пункте 2.2.8 изможено: «Партия ведет работу с молодежью, привлекает ее к участию в осушествлении молодежной политики Партии, способствует формированию молодой смены помитически активных граждан, раздемяющих идеологию Партии» [2] . «ЕАиная Россия» не единственная партия, которая выделяет молодежную аудиторию в отдельную категорию. В Уставе Коммунистической партии Российской Федерации в раздеме «Взаимоотношения КПРФ с органами государственной власти, органами местного самоуправления, политическими партиями и обшественными объединениями», пункт 9.7 посвящен взаимодействию с молодежью: «КПРФ и ее структурные подразделения в работе с молодежью опираются на Аенинский Коммунистический Союз Молодежи Российской Федераџии и иные коммунистические молодежные объединения, сотрудничают с Аругими молодежными организаџиями соџиалистической и патриотической ориентации...» [3]. В Уставе $\Lambda \Lambda П Р$ (пункт 2.2 раздела целей и задач партии) раскрывается суть взаимоотношений партии с молодежью: « $\Lambda$ ПР ведет работу с молодежью, сотрудничает с заинтересованными момодежными организаџиями патриотической направленности, привлекает их к разработке и реализаџии молодежной политики $\Lambda$ АПР [4]. В Уставе «Справедиивой России» тема молодежи не раскрывается, но в программе партии существует отдельный раздел, в котором приводится оџенка молоАежи: «Сегодня значительная часть российской молодежи остается группой соџиального риска. Невозможность реализовать себя приводит к росту экстремизма и насилия в молодежной среде». Эта партия считает госуАарственную политику в отношении молодежи неэффективной и приводит перечень преАложений, который должен способствовать достижению цели, также декмарируемой в программе партии: «Наша цемь - воспитание свободного, образованного, культурного, патриотически мысляшего гражданина Россииџ [5] .

Таким образом, можно отметить высокую степень сходства в понимании партиями молодежной аудитории. Но в программных документах и уставах парламентских партий молодежь упоминается в разном качестве, к ней аАресуются отличающиеся по своей сути послания, а следовательно, и понимается «молодежь» партиями в нескольких смыслах. Во-первых, молодежь определяется как особая целевая аудитория, со специфическими запросами и требованиями, требующая к себе особого подхода в работе. Во-вторых - как каАровый потенциал, от которого зависит будущее страны. В-третьих - как партийный кадровый ресурс, который может стать важным әмементом во время әмекторального противостояния партий. В-четвертых - как потенџиально опасный ресурс, способный стать основой дАя протестного Авижения в России. ОАнако все партии сходятся в понимании молодежи в качестве партийной молодежной ячейки, молодежного партийного кадрового резерва, потенциальных кандидатов дмя внутрипартийных, муниципальных, регионамьных и государственных выборов [6] . 
Время от времени, в основном в преддверии федеральных выборов, Аидеры или преАставители партий обращаются к молодежи, всячески подчеркивая значимость молодых мюдей Амя партии [7]. В своих заявлениях партийные деятели предлагают варианты и способы решения молодежных проблем, активно приглашают молодых Аюдей к участию в партийных и политических делах. В заявлениях все выглядит достаточно ярко и красочно, однако на практике, во время определения кандидатов дмя выдвижения на выборы федерального значения, вспоминают ки партийные мидеры о своих воззваниях? Попытаемся выявить роль, которую сыграла молодежь в рамках выборной кампании в Государственную Ауму Российской Федераџии для парламентских партий, и какое количество молодых мюдей были выдвинуты от партий в качестве кандидатов, сумели одержать победу и представляют сегодня интересы своих избирателей.

Руководствуясь этой целью, проанализируем работу, которую вели молодежные отделения паркаментских партий в довыборный период подготовки к электоральному џиклу, а также насколько молодежь оказалась активной и полезной Амя своих старших товарищей во время избирательных кампаний, какие проекты и акџии они проводили. И наконец, в-третьих, как эти заскуги были оџенены, то есть, какое количество молодых мюдей действительно смог$\Lambda и$ принять участие в главных выборах страны (федеральный парламент) в качестве кандидатов и сколько из них получили заветный мандат.

Исследуемый период ограничен следующими датами: конещ 2015 г., когда первые молодежные организации уже заявили о своей подготовке к избирательной кампании (например, МГЕР), и конец сентября 2016 г., когда итоги голосования были утверждены Центральной избирательной комиссией РФ.

Попытаемся оџенить активность молодежных отделений парламентских партий РФ до офиџиального старта избирательной кампании 2016 г. в ГосуАарственную Ауму VII созыва. Каждое молодежное отделение парламентских партий имеет за плечами собственную историю становмения и развития организации, своих мидеров и уникальный стиль ведения работы с аудиторией. Аеятельность партийных молодежных организаций, как правицо, наибольшей интенсивности достигает при подготовке к выборам [8] .

На наш взгляА, наиболее масштабно и активно к вопросу подготовки выборов подошли в МГЕР. Быц запущен масштабный молодежный проект «АвангарА», который по стицистике Аубцировац преАстоящее преАварительное внутрипартийное голосование партии «ЕАиная Россия» с той цишь разницей, что МГЕР призывала к участию целые молодежные штабы, а не только кандидатов. В попытке организовать контроль за реализаџией проекта каждому участнику присваивалась "роль» и задачи согласно интересам. Помимо самого кандидата, в предвыборный молодежный штаб были вкцючены такие молодежные «должности», как соџиолог, юрист, дизайнер, политолог, технолог, пиар-менеАжер, руководитель избирательного штаба и Аругие.

Затем МГЕР начала не менее масштабную работу по организаџии так называемых «МИШ 2016» - молодежных избирательных штабов, которые 
действовали на территории большинства субъектов РФ и координировались Федеральным молодежным избирательным штабом в Москве. Федеральный МИШ был организован 19 апремя 2016 г., по заявлению организаторов в него вошии следуюшие молодежные организации: ВОО «Молодая Гвардия «ЕАиной России»», «Российский Союз молодежи», «Российские студенческие отряды», «Российский союз сельской молодежки», Молодежный парламент Российской Федерации, молодежное крыло «Российского союза спасателей» [9] .

За месяџ до дня предварительного голосования, 23-24 апреля 2016 г., МГЕР совместно с ЦИК и «ЕАиной Россией» провели образовательный форум, в рамках которого более 200 человек прошли курсы обучения подготовки к Аумским выборам. На форуме приняли участие представители семидесяти регионов России. Такая активная подготовка МГЕР к выборам объясняется тем, что на этот раз молодежному крылу партии власти не была предоставлена «молодежная квота». Центральными органами партии было принято решение не давать молодым дополнительных преференций в партийном списке, но создать возможность наравне с Аругими кандидатами побороться за место в рамках предварительного голосования. В результате по итогам предварительного голосования в составе федерального списка партии «ЕАиная Россия» на выборах в Государственную Ауму смогли выдвинуться десять «молодежных» кандидатов: Артем Туров, Алена Аршинова, Мария Кожевникова, Екатерина Стенякина, Иван Азюбан, Алексей Коробейников, Георгий Головин, Константин Канунников, Сергей Аужников, Артем Малащенков [10] .

По итогам подсчета голосов в единый день голосования 9 сентября 2016 г. получить заветный мандат смогли только двое молодогвардейцев - А. Аршинова и А. Туров. Оба депутата уже были в составе прошлого созыва Аумы и стали депутатами не в первый раз: А. Аршинова (31 гоА) в шестом созыве Государственной Аумы занимала домжность зампреда комитета по образованию, получив свой мандат в конџе марта 2012 г., после ухода К. Косачева. А. Туров (32 года) стал депутатом Государственной Аумы в октябре 2015 г., после ухода $Ф$. Клинцевича, перешедшего в Совет Федерации.

Молодежное крыло КПРФ оказалось менее активным в преддверии выборов. Из ключевых событий этого периода можно выделить традиџионное об-

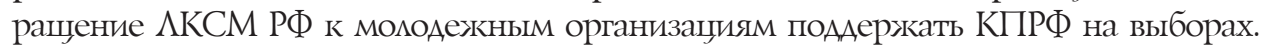
Так, 23 июня 2016 г. в Подмосковье состоялся XV Пиенум ЦК АКСМ РФ. Рассматривался основной вопрос «Положение и место студентов в современной России. Роль Аенинского комсомола в борьбе за права студентов». В рамках пленума бымо принято несколько решений, затрагивающих интересы молодежи: о проведении всероссийской комсомольской акџии протеста под мозунгом «Экономить на студентах - экономить на будущем»; организаџии всероссийского слета молодежи «Комсомольское мето - 2016» во всех федеральных округах; об участии делегаций $\Lambda$ КСМ РФ во всех значимых молодежных форумах («Территория смыслов» на Клязьме, «Иволга» и Ар.). ЦК АКСМ РФ обратился к молодежи России с просьбой поддержать на предстоящих думских выборах КПРФ [11] . 
Заслужила особого внимания работа областного џентра политической учебы КПРФ в Астраханском обкоме (20 января - 30 марта). Это первый по-

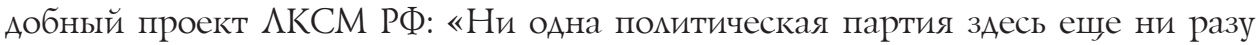
не проводила открытые бесплатные курсы для развития молодежи», - заявмяли организаторы. Записаться на учебу могли не только коммунисты и комсомольцы, но и все желающие [12]. Событием стало подписание Аенинским комсомолом меморандума о подлержке КПРФ на выборах в Госауму. «На выборах 18 сентября мы заявляем о поддержке КПРФ и ее кандидатов. Призываем своих соотечественников активно поддержать нашу позиџию». 30 августа 2016 г. меморандум подписали и другие общественные организации, симпатизирующие коммунистам [13]. АКСМ РФ систематически использовац поводы, предоставленные деятельностью оппонентов, в первую очередь партией «Единая Россия», Амя организации «контрпропагандистских акщий» [14] .

В результате, по информации отдела ЦК КПРФ, более двадџати членов $\Lambda$ КСМ участвовали в выборах в Государственную Ауму по федеральному списку партии, более пятнадџати - по одномандатным округам. Активно прояви$\Lambda$ себя преАставители партии в борьбе с фальсификациями. В целом члены молодежного крыла занимались контролем на выборах, были наблюдателями, чценами УИК, проводили агитацию. ОАнако на результате, выраженном в количестве мандатов для молодежных кандидатов от КПРФ, это отразилось мало. Самым молодым депутатом Государственной Аумы VII созывf от КПРФ стал 29-метний Аенис Парфенов, глава комиссии по работе с молодежью при МГК КПРФ.

$\Lambda А П Р$, будучи всегда «на короткой ноге» с молодежью, преуспела в результативных показателях. Она офищиально признана самой «молодой» фракцией (средний возраст кандидатов 38 мет), преАставленной в Государственной Ауме VII созыва. Василию Власову, руководителю молодежного крыма $\Lambda \Lambda$ ПР 21 год. «Партийный список $\Lambda \Lambda П Р$ был распределен на более чем 130 подгрупп, и в основном первые и вторые места занимали руководите$\Lambda$ региональных ячеек молодежной организаџии $\Lambda \Lambda$ ПР. Например, в Туле Александр Маринков, руководитель молодежного крыла регионального отдемения партии, шел вторым номером в списке. Если сравнивать с Аругими партиями, участвовавшими в выборах, то подавляющее большинство молодых кандидатов было в списках партии $\Lambda \Lambda П Р »,-$ заявцял В. ВАасов. В Госдуму от $\Lambda \Lambda$ ПР прошел и 25-летний Борис Чернышев, координатор московского отделения партии. Такую высокую результативность по количеству «молодежных мандатов» предваряла активная работа молодежной организации $\Lambda А П Р ~$ в соџиальных сетях и на улиџах. Единой программы действий или крупных

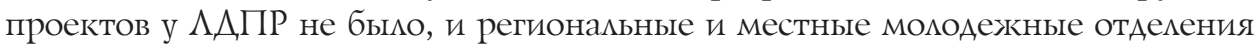
по собственному усмотрению выстраивали работу с электоратом. КаАровый отсев и формирование списка кандидатов тоже проходили в штатном режиме, в соответствии с показателями за предыдущие годы работы в партийной структуре [15]. 
Молодежное отделение партии «Справедливая Сияа», вслед за «материнской» партией «Справедливая Россия» не отличилось особой активностью в подготовке к избирательной кампании, не проявив себя ни в рамках подготовки к избирательной компании, ни во время ее непосредственного проведения. Хотя партией были запушены некоторые молодежные проекты, например, молодежжный кадровый резерв «Справедмивой России», который 25 марта 2016 г. открывал председатель партии С. Миронов. Кадровый резерв пополнялся Ао начала непосредственной избиратемьной кампании партии, и решением партийного съезда из молодежного кадрового резерва в список кандидатов на выборы в Государственную Ауму попали около 40 кандидатов. Но провальные результаты партии на выборах не позволили «Справедливой России» вкАючить в состав Госаумы ни одного "молодежного» кандидата. «Процентов 15 из нашего списка было молодых кандидатов. В Госдуму никто из них не прошем», - рассказал председатель соџиал-демократического Союза молодежи «Справедливая сила» Илья Свиридов.

Таким образом, по результатам работы молодежных организаций разных партий количество молодежных мандатов в VII созыве Государственной Аумы напрямую было связано с результативностью и эффективностью работы самих партий. Но «перекосы» все же есть: не совсем понятно, например, соотношение молодежных мандатов у партии власти, в соответствии с масштабностью работы молодогвардейџев, и количеством мандатов (343) партии «ЕАиная Россия» в нижней палате парламента. Возникает подозрение, что это скорее политическое решение элит внутри партии, чем соблюдение принџипа: «дорогу молодым». Иная ситуация в $\Lambda А П Р$, которая формировала свой список кандидатов из большинства молодых мюдей, и в итоге места в Государственной Ауме получила. КПРФ, имеющая 42 кресла в парламенте, провела только одного молодого кандидата, а «Справедливая Россия» оказалась в «молодежных аутсайдерах».

Явной становится разница в декларируемых и фактических позиџиях пармаментских партий по отношению к молодежи и своим молодежным отделениям. Заявмяя стремление поддержать и опереться на молодые, перспективные каАры, на самом деле партии не торопятся обновцять свои составы. Это в очередной раз подтверждает, что роль молодежи в глазах федеральных партий сводится прежде всего к использованию в качестве инструмента достижения тактических задач избирательной кампании, а не стратегических цемей партийной организаџии.

\section{Библиографический список}

1. Бондарь Н.Н. Молодежь и выборы // Общество и право. 2011. № 4 (36).

2. Устав партии «Единая Россия». URL: https://er.ru/party/rules/

3. Устав КПРФ. URL: https://kprf.ru/party/charter

4. Устав ЛДПР. URL: https://ldpr.ru/party/ustav/

5. Программа партии «Справедливая Россия». URL: http://31.44.80.183/files/pf59/075833.pdf

6. Шумилов А.В. Факторы формирования электоральной политики в молодежной среде // PolitBook. 2012. № 1. 
7. Медведев оценил усилия молодежи / ИА «ВРЕМЯ МН» 27 сент. 2016 г. URL: http://vremyamn.ru/medvedev-otsenil-usiliya-molodezhi-58.html

8. Пастухова Л.С. Молодежь в обновлении органов законодательной власти: тенденции и перспективы // Власть. 2011. № 8.

9. В преддверии выборов 2016 года лидеры молодежных организаций объявили о создании Федерального молодежного избирательного штаба, URL: http:/www.molgvardia.ru/ nextday/2016/04/19/87572

10. ЦИК и «Единая Россия» подготовят «Молодую гвардию» к праймериз и выборам. URL: https://life.ru/t/политика/403195

11. Ленинский комсомол призывает молодежь России поддержать КПРФ на выборах. URL: https://kprf.ru/activity/young/156533.html

12. Первый выпуск Астраханского центра политической учебы / Пресс-служба Астраханского областного отделения ЛКСМ РФ от 11 апр. 2016 г. URL: http://komsomolrf.ru/ru/news/ education/4236-pervyj-vypusk-astrakhanskogo-tsentra-politicheskoj-uchjoby

13. Ленинский комсомол подписал меморандум о поддержке КПРФ на выборах / Прессслужба ЦК ЛКСМ РФ от 30 авг. 2016 г. URL: http://komsomolrf.ru/ru/news/4510-leninskijkomsomol-podpisal-memorandum-o-podderzhke-kprf-na-vyborakh-3

14. Крымский Комсомол во время прймериз «Единой России» привлек больше народу, чем было на избирательном пункте / Пресс-служба ЦК ЛКСМ РФ от 24 мая 2016 г. URL: http:// komsomolrf.ru/ru/news/politics/4350

15. Обновленная власть: молодежный «прорыв» не произошел. 26 сент. 2016 г. URL: https:// life.ru/t/политика/obnovlionnaia_vlast_molodiozhnyi_proryv_nie_proizoshiol

146 Bulletin of the Volga Region Institute of Administration • 2017. Vol. 17. № 3 